\title{
Volatile Organic Compound Emissions from a Landfill, Plume Dispersion and the Tropospheric Ozone Modeling
}

\author{
Sérgio M. Corrêa, * Carolina V. de Souza, Eduardo D. Sodré and Jorgina R. Teixeira \\ Universidade do Estado do Rio de Janeiro, Rodovia Presidente Dutra km 298, \\ 27537-000 Resende-RJ, Brazil
}

\begin{abstract}
Este trabalho avaliou as emissões de compostos orgânicos voláteis (VOC) de um aterro controlado localizado na cidade de Niterói, RJ, Brasil. Foram coletadas 26 amostras em 2009 usando uma câmara de fluxo de cloreto de ponivinila $(\mathrm{PVC})$ cilíndrica de $30 \mathrm{~L}$. Os resultados indicaram uma elevada emissão de $1980 \mathrm{~kg} \mathrm{~km}^{-2} \mathrm{~h}^{-1}$. Um modelo de dispersão Gaussiano foi usado para avaliar o transporte dos poluentes e valores de $525 \mu \mathrm{g} \mathrm{m} \mathrm{m}^{-3}$ para VOC foram encontrados a ca. $500 \mathrm{~m}$ do aterro. As emissões também foram compiladas com dados meteorológicos usando o modelo de trajetórias OZIPR (Ozone Isopleth Package for Research) acoplado ao modelo químico SAPRC (Statewide Air Pollution Research Center) para avaliar o impacto na formação de ozônio troposférico. Os resultados indicaram um aumento de mais de $1000 \%$ nos níveis de ozônio comparados com valores da região metropolitana do Rio de Janeiro. Os resultados indicaram que é necessária uma maior atenção dos órgãos governamentais no gerenciamento dos resíduos sólidos no Brasil.
\end{abstract}

This work evaluated the volatile organic compound (VOC) emissions by a landfill located in Niterói City, RJ, Brazil. Twenty six samples were collected in 2009 using a 30 L cylindrical polyvinyl chloride (PVC) flux chamber. The results indicated an elevated emission of $1980 \mathrm{~kg} \mathrm{~km}^{-2}$ $\mathrm{h}^{-1}$. A Gaussian plume dispersion model was used to evaluate the transport of pollutants and values of $525 \mu \mathrm{g} \mathrm{m}^{-3}$ for VOC were found at $c a .500 \mathrm{~m}$ from the landfill. The emissions were also compiled with meteorological data, using the OZIPR (Ozone Isopleth Package for Research) trajectory model coupled with SAPRC (Statewide Air Pollution Research Center) chemical mechanism to demonstrate the impact on tropospheric ozone. The results indicated a $1000 \%$ increase in ozone in the region of the landfill when compared to the ozone values for the metropolitan region of Rio de Janeiro. The results show that it is necessary greater attention to the political management of municipal solid waste in Brazil.

Keywords: volatile organic compounds, modeling, plumes, ozone, landfill

\section{Introduction}

The final disposition of municipal solid waste in Brazil is done by several ways: $53 \%$ of municipalities put their solid waste in the open way, $1 \%$ in flood plains and $16 \%$ in controlled landfills. ${ }^{1}$ These dumps constitute potential pollution sources which negatively affect the environmental in the regions under their influence. Among the problems arising from this inadequate provision, the main are the pollution of air, water and soil.

Niterói City (Rio de Janeiro State, Brazil) is not an exception to the general situation found in Brazil, and its municipal solid waste is disposed in a landfill in an area known as Morro do Céu (ACMC). This landfill arouses

\footnotetext{
*e-mail: sergiomc@uerj.br
}

particular interest because it is located near a residential center in a watershed zone that should be protected by law. It is officially considered as one of the sources responsible for the degradation of Guanabara Bay (Rio de Janeiro State). No technical study was conducted prior to choosing this area as a landfill, and no capable infrastructure was installed to prevent the damage resulting from the daily disposal of garbage tons. The adjacent region to the landfill has suffered several environmental and health problems that have affected the welfare of the population residing there. ${ }^{2}$

Once municipal solid waste is placed in a landfill, a complex sequence of biologically, chemically and physically mediated events occurs, resulting in gaseous and liquid emissions. A significant fraction of the biodegradable portion of the municipal solid waste is ultimately converted 
to gaseous end-products during the predominately anaerobic stabilization of solid waste organic fractions. Because they are not well-constructed, these uncontrolled landfills have become potential sources of volatile organic compound (VOC) emissions to the atmosphere. Besides being harmful to humans and to the environment, some VOCs also have a significant influence on the tropospheric ozone formation, a secondary pollutant harmful to the environment and to humans. Ozone in the troposphere occurs through the interaction of VOC, nitrogen oxides $\left(\mathrm{NO}_{x}\right)$ and sunlight. The amount of ozone generated depends on the $\mathrm{VOC}$ and $\mathrm{NO}_{x}$ $\left(\mathrm{NO}+\mathrm{NO}_{2}\right)$ concentrations, and the $\mathrm{VOC} / \mathrm{NO}_{\mathrm{x}}$ ratio, the amount of sunlight and meteorological parameters. When VOCs contain reactive molecules (generally unsaturated hydrocarbons such as olefins, alkynes, carbonyls and , to a lesser extent, aromatic and cyclic compounds), the potential for ozone formation in the troposphere is increased.

Therefore, the purposes of this work were to quantify the total VOC emissions from this landfill, estimate the extent of the transport to the neighbourhood and evaluate the impact on tropospheric ozone formation.

In this project, the VOC emissions from the landfill soil were quantified by sampling and gas chromatography analyses. For the transport and diffusion of pollutants, it was used a Gaussian dispersion model which provides the pollutant concentrations in the surroundings as a function of time from the meteorological, topographic and emissions data. The impact of landfill VOC emissions on ozone formation was evaluated using the empirical trajectory atmospheric model OZIPR (Ozone Isopleth Package for Research) coupled with SAPRC (Statewide Air Pollution Research Center) chemical model. This chemical model is based on the widely accepted assumption that the chemistry of VOC and $\mathrm{NO}_{\mathrm{x}}$ leads to the formation of ozone, and that a change in a single individual VOC can lead to unexpected results. When the $\mathrm{VOC} / \mathrm{NO}_{x}$ ratio is low, the $\mathrm{O}_{3}$ rate of formation is controlled by VOC and, conversely, when $\mathrm{VOC} / \mathrm{NO}_{\mathrm{x}}$ ratio is high, the control is done by $\mathrm{NO}_{\mathrm{x}}$. A more detailed description of the physical and chemical aspects of the model are given in our earlier works..$^{3-5}$

The modeled ozone levels for the landfill were compared to the ozone levels for Rio de Janeiro Metropolitan Area (RJMA), region in which the landfill is inserted.

\section{Experimental}

Volatile organic compound (VOC) emissions

Current methods for determining gas emission rates from sub-surface sources can be classified as direct or indirect emission rate measurement techniques.
Indirect measurement methods of the emission rate are: (i) concentration-profile (C-P) techniques and (ii) transect techniques. These techniques involve the measurement of ambient air concentrations under appropriate meteorological conditions. To calculate gas emission rates using these techniques, the ambient air concentration measurements are combined with atmospheric dispersion models to determine emission rates. Direct emission rate measurement methods are: (i) vent sampling techniques, (ii) passive sampling techniques and (iii) flux chamber techniques. In addition, ambient air and sub-surface gas concentrations can be measured using integrated source sampling techniques and soil gas probes. ${ }^{6}$

The flow chamber was chosen as the most appropriate sampling method to obtain emission data from the landfill because it provides greater accuracy, simplicity and flexibility than other methods. ${ }^{6}$ Although slow, the method has undergone validation tests in municipal solid waste landfills in Florida State in U. S. A. ${ }^{6}$ A flow chamber allows the measurement of the VOC flow rates from the soil or from surfaces such as landfill solid waste. The procedure involves placing a closed chamber on the surface of the emission source. A controlled, clean, dry air atmospheric flow passes through the chamber continuously and mixes with the emissions, exiting through a valve at the top of the chamber. The concentrations of the emitted species of interest are measured in the exit gas, which then were used to calculate the emission rate of each species.

The cleaning of atmospheric air was performed using two pre-filter: an activated carbon $(200 \mathrm{~g})$ to trap hydrocarbons and another of silica (200 g) to reduce humidity.

Concentrations of pollutants are measured in the gas output and used to determine emission rates of the VOC species. Figure 1 shows the sampling scheme using the flow chamber method.

In this study, a $30 \mathrm{~L}$ cylindrical PVC (polyvinyl chloride) flow chamber (surface area of $0.1256 \mathrm{~m}^{2}$ ) was used. The open side of the chamber was inserted into the soil to a depth of $5 \mathrm{~cm}$ and samples were collected using a valve positioned at the bottom closed side. The dimensions of the flow chamber were similar that values quoted by Cooper and Reinhart. ${ }^{6}$

Six preliminary samplings were carried out, changing the flow rate and sampling time until the minimum time to collect sufficient material for chemical analyses was determined. This minimum time was selected due to difficulties in accessing the site, because of the unpleasant odor and because the site lacked personal security.

After the step to select the optimum variables, four visits were made to the landfill area to obtain the emission factor 


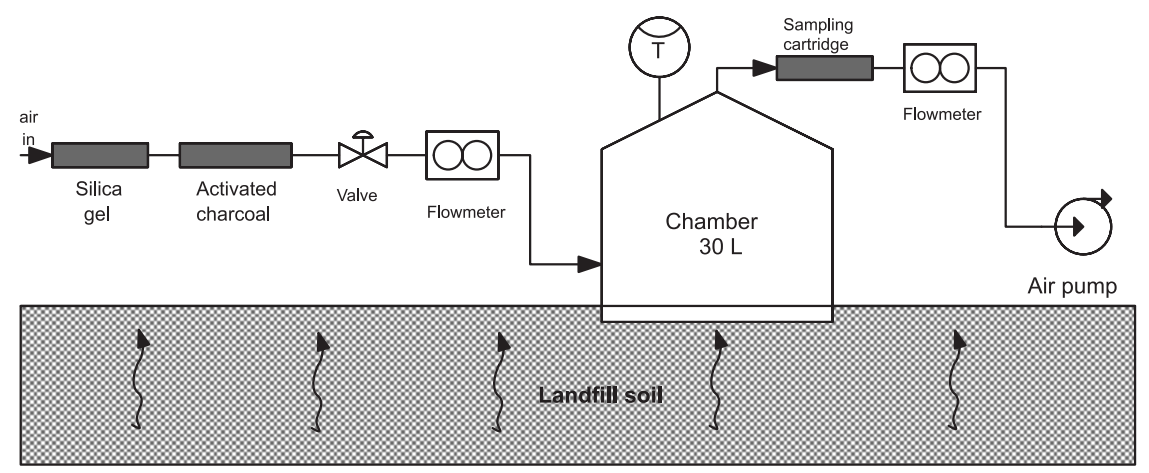

Figure 1. Flow chamber method diagram.

data. Twenty sample collections were carried out: three on $5 / 30 / 2009$, three on $05 / 31 / 2009$, ten on $12 / 01 / 2009$ and ten on $12 / 04 / 2009$, sampling each point for a period of $10 \mathrm{~min}$. The twenty sampling sites were chosen depending on availability, and were at least $20 \mathrm{~m}$ apart. Areas where recent garbage dumping had occurred or where there were puddles of water were avoided.

The gas samples were collected by a battery-operated air pump (SKC, model PCRX4) with a flow rate of

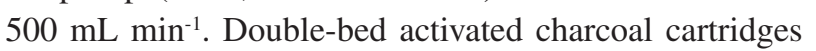
(400/200 mg) (SKC 224-09) were used and the air flow was controlled by flowmeters (Dwyer MMA-20).

The sampled cartridges were sealed, identified, protected from light by aluminum foil, maintained cool in a blue-ice box and transported to the laboratory. Additional data were collected using a portable meter Thal-300, such as temperature, pressure, wind direction and intensity, relative humidity and luminosity were collected during the sampling periods. These measured data would serve to explain anomalous data, which were not found.

The first six samples were analyzed on a 6820 Agilent gas chromatograph, using a HP-1 capillary column $(30 \mathrm{~m} \times 0.32 \mathrm{~mm}, 0.25 \mathrm{~mm})$. Helium was used as the mobile phase at $1.2 \mathrm{~mL} \mathrm{~min}^{-1}$, with a splitless injection volume of $1.0 \mu \mathrm{L}$ at $200{ }^{\circ} \mathrm{C}$ and a flame ionization detector at $250^{\circ} \mathrm{C}$. The column temperature was $40^{\circ} \mathrm{C}$ for 4 min, followed by a heating ramp of $10{ }^{\circ} \mathrm{C} \mathrm{min}^{-1}$ to $220^{\circ} \mathrm{C}$

Because operational problems with the first gas chromatograph, the other twenty samples were analyzed on a Varian 450 gas chromatograph equipped with a Varian 220 mass spectrometer (ion trap), using a VF-5MS capillary column $(30 \mathrm{~m} \times 0.25 \mathrm{~mm}$ thick, $0.25 \mathrm{~mm})$. Helium was used as mobile phase at $1.2 \mathrm{~mL} \mathrm{~min}^{-1}$, with a splitless injection volume of $1.0 \mu \mathrm{L}$ at $200{ }^{\circ} \mathrm{C}$, a transfer liner at $220{ }^{\circ} \mathrm{C}$ and an ion trap at $150{ }^{\circ} \mathrm{C}$. The mass spectrometer was operated in SCAN mode from 45 to $350 \mathrm{~m} / \mathrm{z}$. The programming of the column temperature was $40{ }^{\circ} \mathrm{C}$ for $4 \mathrm{~min}$, followed by a heating ramp of $10{ }^{\circ} \mathrm{C} \min ^{-1}$ to $220^{\circ} \mathrm{C}$.
The quantification of the 26 samples was performed against alkane, alkene and aromatic standard mixtures (BTEX mixture at $1 \mathrm{ppm}, 1$-olefin mixture at $1 \mathrm{ppm}$, paraffin mixture at $1 \mathrm{ppm}$, all from Scott Specialty Gases). The limit of detection (LOD) of each VOC is better than $0.3 \mathrm{ppb}$. This procedure was due to the numerous species present in the emissions and due to lack of chromatographic standards for all species.

The emission rate was calculated by equation 1 :

Emission $=\frac{\mathrm{CV}}{\mathrm{tA}}$

where $\mathrm{A}=$ surface area of the chamber, $\mathrm{t}=$ sampling time, $\mathrm{V}=$ volume of the flux chamber and $\mathrm{C}=$ concentration of the species.

\section{Plume dispersion modeling}

For study the transport and diffusion of pollutants, it was used a Gaussian atmospheric dispersion model implemented in the subroutine ISCSC3 (U.S. Environmental Protection Agency, U.S. EPA).

The diffusion and transport of pollutants were calculated using meteorological, topographic data and VOC emissions. The meteorology and topography data of the study area should be considered because they influence how the plume disperses in the vicinity of the landfill. This model does not include chemical reactions in the atmosphere. Its relevance is determined considering the weather and terrain to which place the plume of contamination from of landfill will tend to move around.

Meteorological data were obtained from the A605 Automatic Weather Station (National Institute of Meteorology, INMET) in Niterói, located at $-22.9063^{\circ} \mathrm{S}$ $-43.1333^{\circ} \mathrm{W}$ and altitude $13 \mathrm{~m}$. Values were daily and hourly obtained for temperature, relative humidity, dew point, atmospheric pressure, wind speed and direction and solar radiation for the period $01 / 01 / 2007$ to $12 / 31 / 2007$, a total of $8760 \mathrm{~h}$. The ideal would be to use data from 2009, 
but it was not possible because the monitoring station was disabled by INMET. As the VOC emission rate from the landfill soil probably did not greatly vary comparing 2007 to 2009 , it was decided to conduct the VOC dispersion modeling for the year of 2007. The topography surrounding the site was obtained from the Google Earth tool, which sets out the Cartesian coordinates and altitude of the region. ${ }^{7} \mathrm{~A}$ grid of $100 \times 100 \mathrm{~m}$ was used to survey the altitude. It was then carried out a survey of the elevation at each vertex of the mesh, thus creating a file in $x, y$ and $z$, where $x$ and $y$ are the coordinates and $z$ is altitude. A contour plot of the $x, y$ and $z$ data is present in Figure S1 at Supplementary Information Section, and the red rectangle in the center of the figure represents the area of the landfill.

\section{Ozone modeling}

The impact of the VOC emitted from the landfill on ozone formation was evaluated using the empirical trajectory atmospheric model OZIPR. ${ }^{8}$ OZIPR allows simulating chemical and physical processes that occur in urban troposphere using a trajectory model. This model can be understood as a column of air at the base that encompasses all the region of the study, and which just up to the mixing layer of the atmosphere, like a box with a movable cover, which is a function of height of the mixed layer throughout the day. The height of the mixed layer indicates the space of the atmosphere which is possible to occur the pollutants vertical dispersion. The emissions from the base of the column are computed as well as wet and dry deposition. The ozone simulation study considers a homogeneous atmosphere, i.e., the pollutants do not suffer the interference of the air masses movement. Basically, the input data for a simulation are the following ones: (i) VOC speciation of the local atmosphere in ppmC (part per million in carbon-based) fraction; (ii) Hourly total VOC, $\mathrm{NO}_{\mathrm{x}}$ and $\mathrm{CO}$ emissions in $\mathrm{kg} \mathrm{km}^{-2} \mathrm{~h}^{-1}$; (iii) Initial concentrations of total VOC, $\mathrm{NO}_{\mathrm{x}}$ and $\mathrm{CO}$ in ppm; (iv) Coefficients of wet and dry deposition for the main pollutants; ( $v$ ) Hourly weather data for temperature, pressure, humidity and mixing height; (vi) Actinic solar flux, that is used to calculate the intensity of sunlight; (vii) Chemical model with chemical reactions and their rate constants.

The output data are the hourly average concentrations of the main chemical species (e.g., $\mathrm{NO}_{x}, \mathrm{CO}, \mathrm{CH}_{4}$, ozone and PAN (peroxyacetyl nitrate)) and secondary pollutants isopleths for several values for $\mathrm{VOC}$ and $\mathrm{NO}_{\mathrm{x}}$.

A simplified flow diagram for the construction of the model is shown in Figure 2.

The chemical model used was the SAPRC model, developed by Carter $^{9}$ and several updates were done in

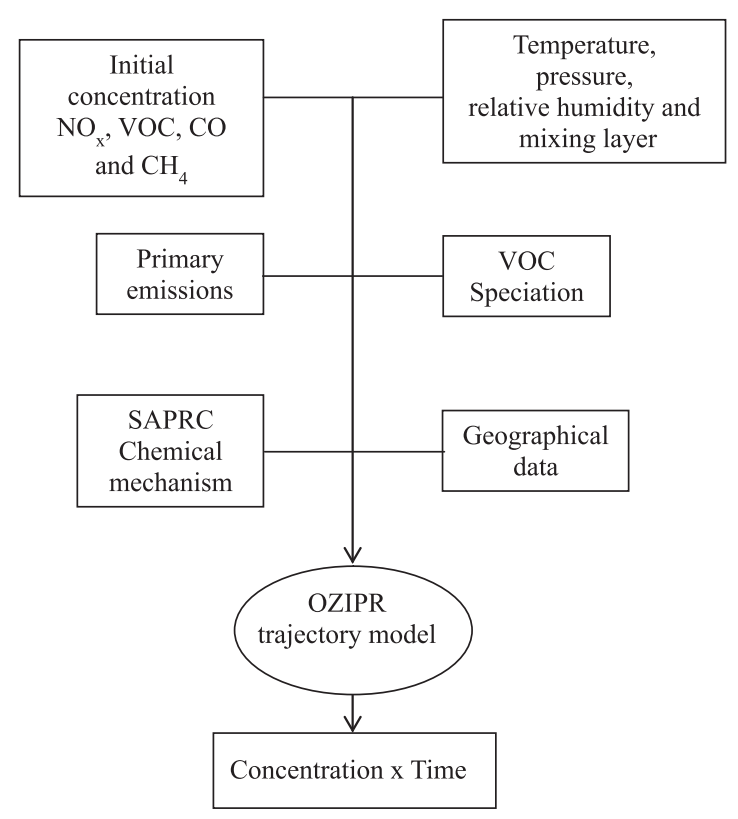

Figure 2. Simplified diagram of the OZIPR model coupled with SAPRC chemical mechanism.

later years. ${ }^{10-16}$ The model was widely tested against 550 controlled experiments in Teflon chambers. The initial version used in this work has 214 reactions and 83 chemical species and other 23 chemical species, and its reactions were recently introduced by our group representing species which frequently occur in Brazilian urban atmospheres as ethanol, some alkenes and aromatics. ${ }^{17}$

Initially, it was made the modeling of the ozone levels for the base case of RJMA, region in which the landfill is inserted. After this initial base case adjustment, it was made the modeling of the ozone levels for the landfill and the results were compared.

To validate the base case, some model input data such as hourly emission data of $\mathrm{CO}, \mathrm{NO}_{\mathrm{x}}$ and VOC were introduced. The hourly mixing height was adjusted to model outputs fit the hourly concentrations of $\mathrm{CO}, \mathrm{NO}_{\mathrm{x}}$ and ozone, which were measured by automatic analyzers (Thermo Environment Instruments).

Input data for modeling the base case

For comparison with samples from the landfill, base case air quality samples were collected adjacent to the downtown area of Rio de Janeiro, using an automatic air quality monitoring station (685978 E and $7465946 \mathrm{~S}$ ). This station collects meteorological data (temperature, humidity, pressure and solar flux) and criteria pollutants $\left(\mathrm{NO}_{x}, \mathrm{O}_{3}\right.$, $\mathrm{SO}_{2}, \mathrm{CO}$, total hydrocarbons and particulate matter). The location and site conditions were the same as described in previous work. ${ }^{4,5,17}$ 


\section{VOC speciation in the local atmosphere}

To use the SAPRC chemical model, the concentrations of the VOC in the local atmosphere should be evaluated in terms of ppmC. This information should be obtained preferably based on measurements of concentration in $\mu \mathrm{g} \mathrm{m}^{-3}$ of the species present in the atmosphere between 6 to 9 a.m., period of higher mobile source emissions during morning rush hour when the influence of photochemical reactions is low.

On the difficulty to represent the chemical model SAPRC with its entire chemical species, a method of grouping into classes was established. In this study, VOCs were grouped into a total of 12 different groups, based on their reactivity with the $\mathrm{OH}$ radical.

Due to the great variety of VOC in the atmosphere, the method of sampling and analysis was split. The first method was designed to sample hydrocarbons in general, and the second method to sample carbonyl compounds. VOC groups used for the simulation of the base case are shown in Table 1. Samplings were collected over three days (June 12, 13 and 15, 2009) at two different times (8 and 9 a.m.) and were collected at $1.5 \mathrm{~m}$ above the ground.

Table 1. VOC groups used for the base case modeling of RJMA and $\mathrm{ACMC}$ (units are given in ppmC and fractions are the sum of a ppmC of total)

\begin{tabular}{|c|c|c|}
\hline VOC or group & $\begin{array}{l}\text { Base case } \\
\text { fraction }\end{array}$ & $\begin{array}{l}\text { ACMC } \\
\text { fraction }\end{array}$ \\
\hline Alkanes 1 (ethane and cyclopropane) & 0.020 & 0.024 \\
\hline Alkanes $2\left(\mathrm{C}_{3}-\mathrm{C}_{4}\right)$ & 0.018 & 0.0209 \\
\hline Alkanes $3\left(\mathrm{C}_{5}-\mathrm{C}_{7}\right)$ & 0.037 & 0.0251 \\
\hline Alkanes $4\left(\mathrm{C}_{8}-\mathrm{C}_{9}\right)$ & 0.032 & 0.0668 \\
\hline Alkanes $5\left(\mathrm{C}_{10}-\mathrm{C}_{22}\right)$ & 0.148 & 0.0166 \\
\hline Ethene & 0.108 & $<$ LOD \\
\hline $\begin{array}{l}\text { Olefins } 1 \text { (propene and higher terminal } \\
\text { olefins) }\end{array}$ & 0.190 & 0.0245 \\
\hline Olefins 2 (acyclic alkenes) & 0.125 & 0.0196 \\
\hline $\begin{array}{l}\text { Aromatics } 1 \text { (benzene and monosubstituted } \\
\text { benzenes) }\end{array}$ & 0.226 & 0.6263 \\
\hline $\begin{array}{l}\text { Aromatics } 2 \text { (xylenes and higher MW } \\
\text { aromatics) }\end{array}$ & 0.057 & 0.1110 \\
\hline Formaldehyde & 0.031 & 0.0093 \\
\hline Acetaldehyde & 0.008 & 0.0043 \\
\hline Aldehydes $>\mathrm{C}_{3}$ & $<$ LOD & 0.0117 \\
\hline Aromatic aldehydes & $<$ LOD & 0.0018 \\
\hline MEK & $<\mathrm{LOD}$ & 0.0013 \\
\hline Terpenes & $<\mathrm{LOD}$ & 0.0172 \\
\hline Acetone & $<\mathrm{LOD}$ & 0.0126 \\
\hline
\end{tabular}

LOD: limit of detection.
Samples for hydrocarbons in general were collected and analyzed following U.S. EPA TO-14 and TO-15 ${ }^{18,19}$ methodologies. It were used $1.8 \mathrm{~L}$ electropolished, stainless-steel, evacuated canisters. To collect each wholeair sample, a stainless-steel valve was slightly opened and the canister was filled to ambient pressure in about $2 \mathrm{~min}$.

The samples were analyzed within three days by gas chromatography with flame ionization detection (GC FID) and mass spectrometry (GC MS), as previously described. ${ }^{3}$

The sample introduction in the gas chromatography (GC) system was done passing the gaseous sample by a sample pre-concentration trap (SPT) cooled at $-180{ }^{\circ} \mathrm{C}$ using liquid nitrogen. A sample volume of $250 \mathrm{~mL}$ was used and was controlled by a mass flowmeter (Sierra Instruments model 902C-OS-BM-I1). This SPT loop is made by stainless steel with $9 \mathrm{~cm}$ long, filled with silanized glass beads with mesh 60/80. After the pre-concentration step the sample quickly heated until $200{ }^{\circ} \mathrm{C}$ and sent to the chromatography column by the mobile phase (Helium 6.0 at $1.8 \mathrm{~mL} \mathrm{~min}^{-1}$ ). The column temperature started at $180^{\circ} \mathrm{C}$, held for $4.5 \mathrm{~min}$, followed by a heating rate of $66.7^{\circ} \mathrm{C} \mathrm{min}^{-1}$ for $7.5 \mathrm{~min}$, then

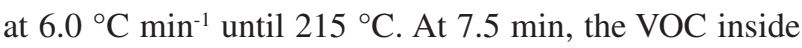
the SPT were transferred to the column.

The GC column used was a DB-1 $(60 \mathrm{~m}, 0.32 \mathrm{~mm}$ and $1.6 \mathrm{~mm}$ ). Using the NIST 98 spectral library was possible to identify 32 VOC ranging from 2 to 9 carbon atoms. Three calibration mixtures were used (Scott Specialty Gases) with 5, 10 e 20 ppbv balanced in nitrogen. Alkanes: methane, ethane, propane, butane, pentane and hexane. Alkenes: ethene, propene, 1-butene, 1-pentene and 1-hexene. Aromatics: benzene, toluene, ethyl benzene and o-xylene.

Samples for carbonyls were collected and analyzed following U.S. EPA TO- $11 \mathrm{~A}^{20}$ methodology, which is based on the reaction of atmospheric carbonyls with 2,4-dinitrophenylhydrazine, to form the respective hydrazones. The samples were collected using silica- $\mathrm{C}_{18}$ cartridges impregnated with acid solution of 2.4-dinitrophenilhydrazine (DNPH), with the same air pump used for the other VOCs, operated at $1.0 \mathrm{~mL} \mathrm{~min}^{-1}$ for $60 \mathrm{~min}$. An ozone trap filled with potassium iodide was used before the DNPH cartridge to avoid the ozone interference. After sampling, the cartridges were sealed, wrapped with aluminum foil and stored at $4{ }^{\circ} \mathrm{C}$ and analyzed prior 3 days. All the procedure is detailed in our previous work. ${ }^{4,21}$

The extraction of carbonyl samples were done using $5 \mathrm{~mL}$ of acetonitrile and the chemical analyses were done by high performance liquid chromatography (HPLC), using a Perkin Elmer Series 200 equipment with UV detection at $365 \mathrm{~nm}$. The mobile phase was $55 \%$ acetonitrile in water at $30{ }^{\circ} \mathrm{C}$, with a $30 \mu \mathrm{L}$ injection and a $\mathrm{C}_{18}$ column 
$(250 \times 4.6 \mathrm{~mm}, 5.0 \mathrm{~mm})$. Calibration was carried out using a standard mixture (Supelco CARB Carbonyl Mix 1) containing formaldehyde, acetaldehyde, acroleína, acetone, propionaldehyde, butyraldehyde and benzaldehyde at concentrations between 0.5 to $10.0 \mathrm{mg} \mathrm{L}^{-1}$, obtaining correlation coefficients better than 0.99 .

Initial concentrations of $\mathrm{VOC}, \mathrm{NO}_{\mathrm{x}}$ and $\mathrm{CO}$

The initial concentrations of $\mathrm{NO}_{x}, \mathrm{VOC}$ and $\mathrm{CO}$ were provided by INEA (Rio de Janeiro State Environmental Institute $)^{22}$ through automatic air quality monitoring stations located in downtown area of Rio de Janeiro. It was used the average values between 6 and 9 a.m. during June 12,13 and 15, 2009. Table 2 shows the initial concentrations of these primary pollutants used for the base case simulation of RJMA.

Table 2. Initial concentrations of primary pollutants used for the base case simulation of RJMA

\begin{tabular}{lc}
\hline Species & Concentration \\
\hline $\mathrm{NO}_{\mathrm{x}}$ & $0.192 \mathrm{ppm}$ \\
$\mathrm{CO}$ & $1.3 \mathrm{ppm}$ \\
$\mathrm{VOC}$ & $0.76 \mathrm{ppmC}$ \\
\hline
\end{tabular}

Hourly VOC, $\mathrm{NO}_{x}$ and $\mathrm{CO}$ emissions

To values of hourly VOC, $\mathrm{NO}_{\mathrm{x}}$ and $\mathrm{CO}$ emissions, it was initially used those reported by the annual emissions inventory released by INEA ${ }^{22}$ (Table 3 ).

Table 3. Hourly emissions of total VOC, $\mathrm{NO}_{\mathrm{x}}$ and $\mathrm{CO}^{22}$

\begin{tabular}{lccc}
\hline Pollutants & $\begin{array}{c}\mathrm{NO}_{\mathrm{x}} / \\
\left(\mathrm{kg} \mathrm{h}^{-1} \mathrm{~km}^{-2}\right)\end{array}$ & $\begin{array}{c}\mathrm{CO} / \\
\left(\mathrm{kg} \mathrm{h}^{-1} \mathrm{~km}^{-2}\right)\end{array}$ & $\begin{array}{c}\mathrm{VOC} / \\
\left(\mathrm{kg} \mathrm{h}^{-1} \mathrm{~km}^{-2}\right)\end{array}$ \\
\hline Hourly emission & 8.61 & 30.54 & 7.54 \\
\hline
\end{tabular}

A subsequent adjust was done on the hourly emissions of $\mathrm{CO}, \mathrm{NO}_{\mathrm{x}}$ and $\mathrm{VOC}$ to a better fit modeled results with experimental hourly concentrations of $\mathrm{CO}, \mathrm{NO}_{x}$ and $\mathrm{O}_{3}$ obtained on 12 June, 2009 which were provided by INEA automatic monitoring station located in downtown area of Rio de Janeiro. These adjustments are described in more details in the Results and Discussion Section.

Data for temperature, pressure, humidity and mixing layer height

Hourly meteorological data of temperature, pressure and humidity were calculated as an average for June, 2009.
The initial and maximum mixing heights were set at 600 and $1600 \mathrm{~m}$, respectively, which are typical values for Rio de Janeiro. ${ }^{23}$ The main effect of the mixing height is the dilution of gases. The actinic solar flux was calculated by OZIPR software using the geographical coordinates and the day of the experiment.

Modeling for the landfill area (ACMC)

As the landfill is located only $30 \mathrm{~km}$ from downtown area of Rio de Janeiro, some input data for base case were also used for the ozone modeling, as the initial concentrations and hourly $\mathrm{CO}$ and $\mathrm{NO}_{\mathrm{x}}$ emissions, deposition rates, mixing layer profile, temperature and humidity data. An additional adjustment was considered unnecessary because the main objective of the simulation was to analyze the effect of VOC emissions (quantity and speciation) from landfill on the ozone formation and not to exactly reproduce a particular day or location. Therefore, the construction of the base case was considered representative of the air quality in the downtown area of Rio de Janeiro.

The VOC speciation in the atmosphere of the landfill was done in June 12, 2009, at two different times (8 and 9 a.m.) and followed the same sampling and analysis methodology described for the downtown area of Rio de Janeiro. The hourly VOC emissions from landfill were assumed constant during the day. The sampling and analysis methods for VOC emissions were previously described.

\section{Results and Discussion}

\section{Volatile organic compound (VOC) emissions}

Several VOCs were found in landfill emissions, including alkanes, olefins, aromatics, chlorinated compounds, carcinogenic VOC (benzene and vinyl chloride), ethylbenzene, methane, toluene, trichloroethane and xylenes. ${ }^{6}, 24$ The average emission rate for the 20 sampling points was $0.58 \mathrm{mg} \mathrm{m}^{-2} \mathrm{~s}^{-1}$ $\left(2088 \mathrm{~kg} \mathrm{~km}^{-2} \mathrm{~h}^{-1}\right)$ with a deviation of $0.15 \mathrm{mg} \mathrm{m}^{-2} \mathrm{~s}^{-1}$, as presented in Figure 3. Vehicular emission values for the metropolitan areas of São Paulo $\left(38 \mathrm{~kg} \mathrm{~km}^{-2} \mathrm{~h}^{-1}\right)^{25}$ and Rio de Janeiro $\left(26 \mathrm{~kg} \mathrm{~km}^{-2} \mathrm{~h}^{-1}\right)^{21}$ are significantly lower than the value found in this work for the landfill studied $\left(1980 \mathrm{~kg} \mathrm{~km}^{-2} \mathrm{~h}^{-1}\right)$. The values of VOC emissions obtained should be considered minimum values since some VOC may not have been retained by the sampling system or they would not have been effectively extracted from the cartridges. These values also do not include methane and reduced sulfur compounds, in which the emissions are 
very high in landfill areas, but were not quantify by the methodology used in our work.

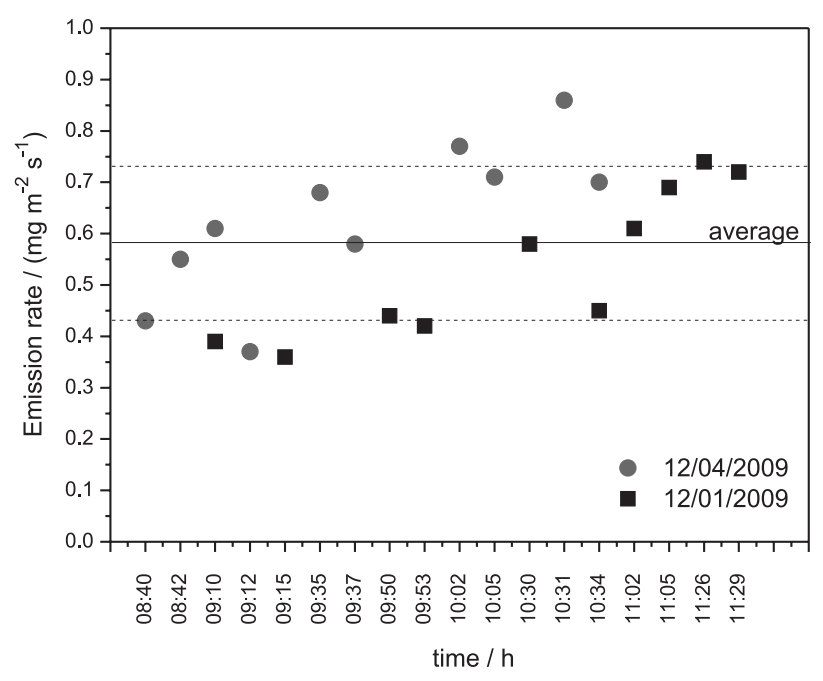

Figure 3. Results for emission rate for the last 20 samples from the landfill, measured at two different days. Solid line indicates the average value and dashed lines the upper and lower standard deviation.

The emission rate measurement from a source area has been rarely described in the literature, unlike emission data from point sources, such as chimneys, where well-established methodologies have been reported. A single study of landfills in Florida State $^{6}$ reports emission rates ranging from $1.1 \mathrm{mg} \mathrm{m}^{-2} \mathrm{~s}^{-1}\left(3.9 \times 10^{3} \mathrm{~kg} \mathrm{~km}^{-2} \mathrm{~h}^{-1}\right)$ to $1.7 \mathrm{mg} \mathrm{m}^{-2} \mathrm{~s}^{-1}\left(6.1 \times 10^{3} \mathrm{~kg} \mathrm{~km}^{-2} \mathrm{~h}^{-1}\right), c a .2-3$ times higher than the values determined in this work. This difference can be attributed to several factors. for example, the type of garbage and its handling, and the landfill type.

\section{Plume dispersion}

The plume dispersion in the surroundings of the landfill could be determined from the average emission rate, the topography and the local meteorological data at the considered time. Different emission scenarios could be constructed based on meteorological data chosen at different times. The scenarios chosen for 1 , 8 and $24 \mathrm{~h}$ were those that throughout the studied year showed the worst conditions of atmospheric dispersion for each period. For 1,8 and $24 \mathrm{~h}$, the calculated peak concentrations of VOC in the surroundings were 525 , 373 and $161 \mu \mathrm{g} \mathrm{m}^{-3}$, respectively. These areas of maximum concentration coincided with important places from the standpoint of public health.

The result of the plume dispersion for $1 \mathrm{~h}$ (Figure 4) shows a large area with a high concentration of pollutants.

Whereas the atmosphere of Rio de Janeiro (an adjacent city to Niterói) displays average VOC values

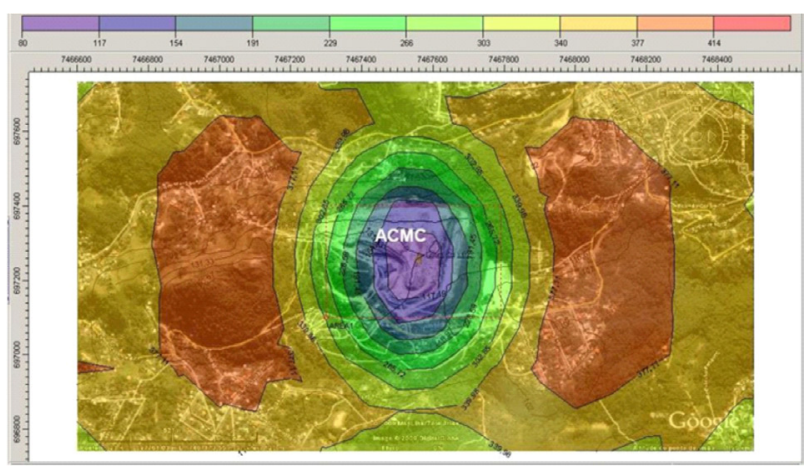

Figure 4. VOC plume dispersion results for the $1 \mathrm{~h}$ scenario for ACMC $\left(\mu \mathrm{g} \mathrm{m}^{-3}\right)$. See on-line for color visualization.

(without considering methane) of $c a .800 \mu \mathrm{g} \mathrm{m}^{-3}$ due to mobile and stationary sources, ${ }^{26}$ the values found in this study represent a considerable contribution to the VOC levels in the region.

\section{Ozone modeling}

Table 1 shows the fractions in ppmC of the VOC groups in the atmosphere of the base case and the landfill.

When running the OZIPR model, a file is generated with hourly concentrations of $\mathrm{CO}, \mathrm{NO}_{\mathrm{x}}$ and $\mathrm{O}_{3}$. These modeled results are then compared with hourly concentration values obtained by automatic monitoring station provided by INEA. ${ }^{22}$ Due to initial differences between modeled and experimental values, adjustments in the hourly emissions of $\mathrm{CO}, \mathrm{NO}_{x} \mathrm{COV}$ and mixing layer are made in order to equalize the maximum values and profiles of $\mathrm{CO}, \mathrm{NO}_{\mathrm{x}}$ and $\mathrm{O}_{3}$ modeled with experimental values.

After these adjustments steps, the model validation through several experimental data was done until the model can be used to estimate the scenarios desired.

The OZIPR model also enables to perform multiple simulations of $\mathrm{O}_{3}$ maximum values for different concentrations of VOC and $\mathrm{NO}_{x}$, providing data that can generate an isopleth plot (lines of equal concentrations). The isopleth plot allows the forecast of ozone levels according to different $\mathrm{NO}_{\mathrm{x}}$ and VOC scenarios. Figure 5 shows ozone isopleth maximum reached for a wide range of concentrations of VOC and $\mathrm{NO}_{x}$ for the RJMA base case.

The region with a gray circle in Figure 5 indicates the actual scenario for RJMA. Figure 5 places RJMA in a situation in which low concentrations of ozone are most influenced by $\mathrm{VOC}$ than $\mathrm{NO}_{x}$ emissions. This means that if

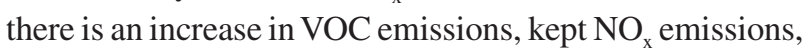
there will be an increase in ozone levels. Otherwise, reducing $\mathrm{NO}_{\mathrm{x}}$ ozone will be increased.

The VOC emissions from the landfill were considered constant throughout the day, with a value of $1980 \mathrm{~kg} \mathrm{~km}^{-2} \mathrm{~h}^{-1}$. 


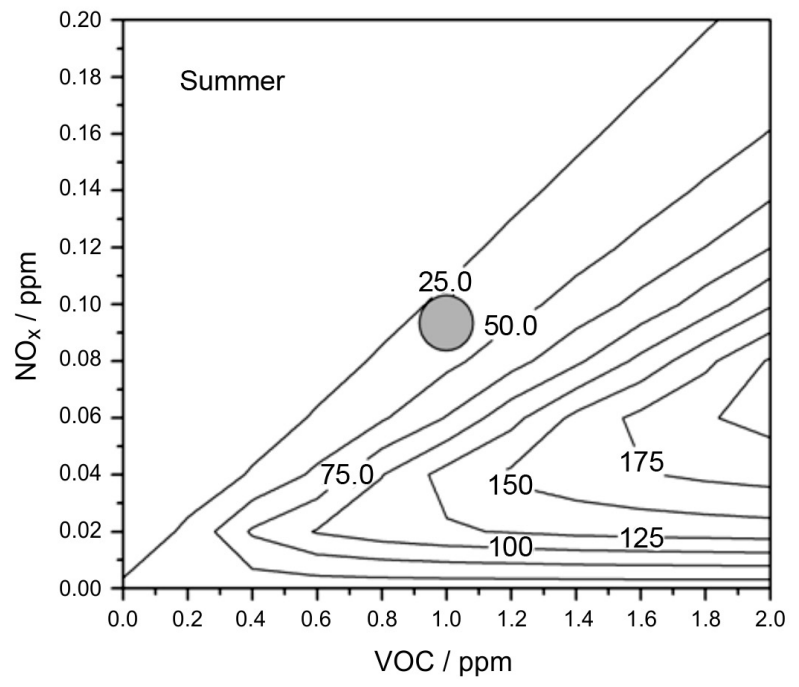

Figure 5. Ozone isopleth plot for Rio de Janeiro Metropolitan Area.

The modeled ozone peak was calculated at 10 a.m. (315 ppb). As a reference, CONAMA (Brazilian National Council on the Environment ${ }^{27}$ states that an average ozone concentration of $160 \mu \mathrm{g} \mathrm{m}^{-3}$ during a one hour period shall not be exceeded more than once per year.

This result indicated that VOC emissions of the landfill representing an increase of more than one thousand percent at the maximum level of ozone in the region, indicating that the VOC emissions from the landfill must be considered.

This increase can be explained by the ratio between the concentrations of VOC and $\mathrm{NO}_{x}$ in RJMA: the landfill is located in a region where an increase in VOC emissions leads to an increase in ozone concentration.

It is important to note that ozone simulation uses a trajectory model, which considers a homogeneous atmosphere, i.e., the pollutants are not diluted with the air mass movements from the surroundings. This is not the case of the Rio de Janeiro Metropolitan Area, with the presence of the Atlantic Ocean, Guanabara Bay and a complex topography. The next step of our group is to use more complex models, as the Eulerian and Lagrangean ones, such as CDMS-Urban, now being developed for our city.

\section{Conclusions}

This study uses a methodology to assess VOC emissions from the soil of a landfill into the atmosphere. This landfill showed high emission rates of several VOCs, which affect the environment and life quality in its surroundings.

The mathematical model used to estimate the plume dispersion proved to be a good tool to generate data that can be used to assess risk situations regarding public health. Schools, churches, hospitals, kindergartens and other places of public health importance are situated in the surroundings of the landfill, and were reached by air pollutants originating from the landfill. As a result, the study stands as a tool for risk analysis, allowing government sectors to determine policies for granting establishment in areas impacted by the plumes.

This study indicates that the emissions contribution from a landfill and its VOC composition contribute to the increase in tropospheric ozone. The results show that it is necessary greater attention to the political management of municipal solid waste in Rio de Janeiro State, including the location choice and the monitoring of landfill areas during and after their period of operation. Many aspects have to be taken in account during the process of landfill planning. The projected landfill has to consider the impact of the plume emissions on its surroundings and the potential to form secondary pollutants such as ozone, a harmful photochemical oxidant.

\section{Supplementary Information}

Supplementary data are available free of charge at http://jbcs.sbq.org.br as a PDF file.

\section{Acknowledgements}

This work was partially supported by Fundação de Amparo à Pesquisa do Estado do Rio de Janeiro (FAPERJ) and Conselho Nacional de Desenvolvimento Científico e Tecnológico (CNPq).

\section{References}

1. Instituto Brasileiro de Geografia e Estatística (IBGE), http:// www.ibge.gov.br/home/estatistica/populacao/condicaodevida/ pnsb/lixo_coletado/lixo_coletado109.shtm accessed in December 2010.

2. Sisinno, C. L. S.; Moreira, J. C.; Cad. Saúde Pública 1996, $12,4$.

3. Martins, E. M.; Arbilla, G.; Bauerfeldt, G. F.; Paula, M.; Chemosphere 2007, 67, 2096.

4. Corrêa, S. M.; Arbilla, G.; Atmos. Environ. 2003, 37, 23.

5. Martins, E. M.; Arbilla, G.; Atmos. Environ. 2003, 37, 1715.

6. Cooper, C. D.; Reinhart, D. R.; Rash, F.; Seligman, D.; Keely, D.; Landfill Gas Emission: Report \#92-2. State University System of Florida, Florida Center for Solid and Hazardous Waste Management, Florida, USA, 1992, 1.

7. Google Earth, http://maps.google.com.br/maps?utm campaign=pt_BR\&utm_source= pt_BR-ha latam-br-bkgm\&utm_medium=ha\&utm_term=google $\% 20$ maps accessed in May 2009. 
8. Gery, M. W.; Crouse, R. R.; User's Guide for Executing OZIPR; U.S. Environmental Protection Agency (U.S. EPA), North Carolina, order No. 9D2196NASA, 1990.

9. Carter, W. P. L.; Atmos. Environ. 1990, 24, 481.

10. Carter, W. P. L.; J. Air Waste Manage. Assoc. 1994, 44, 881.

11. Carter, W. P. L.; Atmos. Environ. 1995, 29, 2513.

12. Carter, W. P. L.; Atmos. Environ. 1996, 22.

13. Carter, W. P. L.; Documentation of the SAPRC-99 Chemical Mechanism for VOC Reactivity Assessment, Final Report to California Air Resources Board Contract No. 92-329 and 95308, 2000, http://citeseerx.ist.psu.edu/viewdoc/download?doi $=10.1 .1 .22 .1337 \&$ rep=rep1\&type=pdf accessed in April 2011.

14. Carter, W. P. L.; Lurmann, F. W.; Atmos. Environ. 1991, 25, 2771.

15. Carter, W. P. L.; Atkinson, R.; Int. J. Chem. Kinet. 1996, 28, 497.

16. Carter, W. P. L.; Luo, D.; Malkina, I. L.; Environmental Chamber Studies for Development of an Updated Photochemical Mechanism for VOC Reactivity Assessment, Draft final report to California Air Resources Board Contract 92-345, Coordinating Research Council Project M-9, National Renewable Energy Laboratory Contract ZF-2-12252-07,1997, http://www.engr. ucr.edu/ carter/pubs/rct3rept.pdf accessed in April 2011.

17. Corrêa, S. M.; Arbilla, G.; Atmos. Environ. 2005, 39, 4513.

18. U.S. Environmental Protection Agency (U.S. EPA); Determination of Volatile Organic Compounds (VOCs) in Ambient Air Using Specially Prepared Canisters with Subsequent Analysis by Gas Chromatography, $2^{\text {nd }}$ ed., Compendium Method TO-14A, Center for Environmental Research Information, EPA/625/R-96/010b, Cincinnati, OH, 1999, http://www.epa.gov/ttnamti1/files/ambient/airtox/to-14ar. pdf accessed in April 2011.

19. U.S. Environmental Protection Agency (U.S. EPA); Determination of Volatile Organic Compounds (VOCs) in Air Collected in Specially-Prepared Canisters and Analyzed by
Gas Chromatography/Mass Spectrometry, $2^{\text {nd }}$ ed., Compendium Method TO-15A, Center for Environmental Research Information, EPA/625/R-96/010b, Cincinnati, OH, 1999, http:// www.epa.gov/ttnamti1/files/ambient/airtox/to-15r.pdf accessed in April 2011.

20. U.S. Environmental Protection Agency (U.S. EPA), Determination of Formaldehyde in Ambient Air Using Adsorbent Cartridge Followed by High Performance Liquid Chromatography (HPLC), Compendium Method TO-11A, Center for Environmental Research Information, EPA-625/R96/010b, Cincinnati, OH, 1997, http://www.epa.gov/ttnamti1/ files/ambient/airtox/to-11ar.pdf accessed in April 2011.

21. Corrêa, S. M.; Arbilla, G.; Martins, E. M.; Quiterio, S. L.; Guimaraes, C. S.; Gatti, L. V.; Atmos. Environ. 2010, 44, 2302.

22. Rio de Janeiro State Environmental Institute (INEA), Annual Report 2009, Rio de Janeiro, Brasil, 2009.

23. Arbilla, G.; Martins, E. M.; Moreira, A.; Moreira, L. F.; J. Braz. Chem. Soc. 2002, 13, 308.

24. Chiriac, R.; Carré, J.; Perrodin, Y.; Vaillant, H., Gasso, S.; Miele, P.; Atmos. Environ. 2009, 43, 1926.

25. Orlando, J. P.; Gatti, L. V.; Alvim, D. S.; Yamazaki, A.; Corrêa, S. M.; Sci. Total Environ. 2010, 408, 1612.

26. Corrêa, S. M.; Air Quality of Rio de Janeiro City: Synergy between Modeling and Monitoring, $\mathrm{PhD}$ Thesis, Instituto de Química, Universidade Federal do Rio de Janeiro, Brasil 2003. Data available upon request from authors.

27. Brazilian National Council on the Environment (CONAMA), Brazil; Sets Standards of Primary and Secondary Air Quality and even the Criteria for Acute Episodes of Air Pollution, Resolution No. 03 from 28 June 1990, Diário Oficial da União, Brasil, 1990, http://www.mma.gov.br/port/conama/ res/res90/res0390.html accessed in April 2011.

Submitted: March 29, 2011

Published online: January 24, 2012 